\title{
Editorial - A Sense of Perspective
}

The fundamental mission of the Cambridge Yearbook of European Legal Studies is to foster a space for sustained reflection and conversation about the challenges facing Europe and the diverse legal contexts in which those challenges are addressed. The challenge of the United Kingdom's withdrawal from the European Union has dominated reflections and conversations in the year since the publication of the previous volume of the Yearbook. Yet it is important to retain a sense of perspective.

First, as significant as 'Brexit' is in political, economic, and legal terms, European institutions continue to address a wide range of contemporary challenges. New initiatives create opportunities for new perspectives such as Cullen's exploration of climate change abatement in the context of EU banking reforms or Ahern's analysis of attempts to invoke shareholder 'stewardship' in reforms to EU corporate governance legislation. Secondly, new perspectives can be brought to more familiar conversations such as Garner's reconceptualization of EU citizenship or Karatzia's discussion of recent developments in the area of the European Citizens' Initiative. A third way of offering a fresh perspective is to take stock and stand back to see how a field has developed in order to consider where it might go. Both Mak's exploration of pluralism in private law and Storskrubb's evaluation of the concept of mutual trust in private law help us to gain a new perspective on a field that is often not at the centre of European Legal Studies. A fourth and familiar method of gaining perspective is to look to comparative analysis. At an institutional level, O'Leary offers fresh insights on the comparative jurisprudence of the EU Court of Justice and the Council of Europe's Court of Human Rights in the areas of surrogacy and religious freedom. At a more doctrinal level, Ward evaluates the consistency and coherence of EU equality law when comparing the interpretation of primary law-the EU Charter of Fundamental Rights - with the interpretation of EU non-discrimination legislation. Whether by offering original points of focus or adopting novel approaches to more familiar subjects, the papers in this year's volume offer us new perspectives on a world of European Legal Studies beyond Brexit.

However, it is still possible to approach Brexit from a fresh perspective. As Tomlinson and Gormsen demonstrate, it is easy for a domestic public law perspective to become overly preoccupied with the role of parliaments and of courts in managing the withdrawal process. That would be to neglect the fundamental impact withdrawal from the EU will have on the capacities and functions of administrative institutions. Using a case study of competition policy, the authors dramatize the problem that Pascal Lamy has so vividly described as taking the egg out of the omelette. In their contribution, Barrett and Butler, also use Brexit to highlight how the Common Travel Area ('CTA') between the UK and Ireland has evolved and how that system for the free movement of people has operated during the EU membership of both countries. The UK and Ireland joined the then EEC at the same time in 1973 
and developments in European integration towards the free movement of peopleincluding Schengen-have happened alongside retention of the CTA. The UK's withdrawal from the EU poses new legal challenges for how this system will work with one party inside the EU and the other outside.

The editors of the Yearbook are pleased to present these new perspectives on European Legal Studies in this year's volume. The Yearbook is a publication of the Centre for European Legal Studies of the Faculty of Law, University of Cambridge. The editors are thankful for the support of the Centre and of its professional administrator Felicity Eves-Rey. They would also like to thank Rebecca O'Rourke and Jamie Davidson from Cambridge University Press for their continuing professionalism in publishing the Yearbook and especially Erin Lovall and Andrew Organ of the Press for ensuring the quality and timeliness of its production.

Cambridge October 2018 